\title{
CAPITAL MARKET DEVELOPMENT AND ECONOMIC GROWTH IN NIGERIA
}

\author{
Adolphus Joseph Toby \\ Department of Banking and Finance \\ Rivers State University, Nigeria \\ E-mail: toby.adolphus@ust.edu.ng \\ Samuel Dibiah \\ Department of Banking and Finance \\ Rivers State University, Nigeria
}

\begin{abstract}
The motivation behind this study is to experimentally look at the connection between capital market improvement and monetary development in Nigeria. The examination investigated the Central Bank of Nigeria quarterly information from 1981Q1 to 2017Q4 with the E-sees programming bundle (variant 9.0). The Vector Auto Regression (VAR) procedure was utilized to investigate the information, while theory testing depended on the Block Exogeneity Wald test. The predetermined models included stationarity tests, diminished structure VAR gauge, and primary examination. The Augmented Dickey-Fuller Test demonstrates that the examination factors are fixed at first contrast or I(1). The VAR establishes plot corresponding to unit circle demonstrates that our predetermined diminished structure VAR models are steady. The Lagrange Multiplier (LM) symptomatic tests demonstrate that our predetermined VAR models are effectively indicated. The p-esteem shows that market capitalization proportion is critical in clarifying varieties in financial development $(p=0.0205)$. Notwithstanding, the worth of stock proportion and banking framework capitalization proportion is not huge in deciding the Real Gross Domestic Product in Nigeria. All in all, capital market advancement in Nigeria is worked with by vigorous market capitalization. Nonetheless, it is restricted by diminishing volume of stock and lessening banking framework capitalization. It is suggested that the monetary area ought to take on forceful capital market drives and vigorous monetary development approaches to support financial development in an arising economy.
\end{abstract}

Keywords: Capital Market Development, Volume of Stock, Market Capitalization, Banking System Capitalization, and Economic Growth.

\section{Background to the study}

\section{INTRODUCTION}

Financial Frameworks are comprised of organizations of monetary business sectors, foundations, organizations, families, and governments that assume dynamic parts in that framework by their interest and by so doing direct its tasks. A solid and created monetary framework can be of colossal advantage to the economy as far as to reserve funds preparation and proficient monetary 
intermediation jobs (Gibson \& Tsakalotos, 1994). Monetary frameworks assume key parts in the economy, particularly in the investment funds speculation development nexus, one of which is to go about as a compelling vehicle for directing assets from surplus to deficiency units by preparing assets and guaranteeing the proficient change of these assets into genuine useful capital, making sufficient liquidity in the economy by assembling the assets present moment and making them accessible long haul, lessening data costs, giving danger the executives administrations and decreasing dangers from the framework through expansion and methods of hazard sharing and hazard pooling; activating investment funds from people with a surplus for speculation, subsequently taking care of the issue of resoluteness in monetary exchanges and activating reserve funds that are put resources into the most useful endeavors regardless of the wellspring of the investment funds. This can be accomplished either by direct market-based financing or by backhanded bank-based money (Levine, 2004; Emenuga, 2004).

Ensuing upon the hypothetical works of Keynes (1936) who advanced government mediation in monetary business sectors, numerous legislatures including those of sub-Sahara Africa of which Nigeria is no exemption had during the 1960s and 1970s made endeavors to produce financial development through monetary severe arrangements, for example, the utilization of fixed loan fees, sectorial credit distribution and inflationary money related approaches. All things considered, McKinnon and Shaw (1973) contended against such monetary abusive strategies as they went about as hindrances to investment funds preparation, which forestalled since a long time ago run financial development and economical turn of events. Following this, creating economies over the most recent couple of many years have inclined towards advancement procedures that focus more on the modernization and progression of their monetary frameworks, sub-Saharan Africa being no special case. Certain activities during the 1980s have seen the greater part of these nations take on arrangements pointed toward decreasing the degrees of monetary constraint by and large watering down the degree of government intercession in public monetary areas, through the privatization of banks and other monetary organizations. These strategies were pointed toward advancing development through the monetary turn of events and this was to be accomplished through higher activation of reserve funds, an increment in homegrown and unfamiliar speculations, and an overall improvement in the proficiency of asset allotment (Cobbina, 1999).

The job of the monetary framework is basic to the advancement of any economy significantly as a result of the tremendous help it gives to financial exercises. The simple presence of a monetary framework isn't sufficient however, subsequently, for quicker development and extension in financial exercises, a sound, and proficient monetary framework should be set up to viably invigorate monetary reconciliation which will achieve the ideal development. In facilitating monetary intermediation, reserves are moved from net savers to net borrowers. The net savers are arranged as the excess unit (financial backers), with a generous measure of inactive assets, while the net borrowers then again are sorted as the shortfall unit (borrowers) in the monetary chain as in they have openings, however, don't have the necessary accounts to take advantage of them. Leaving them all alone, these units would think that it is undeniably challenging and practically difficult to sort out the relating job they need to play. It follows accordingly that, to save cost and time, the monetary framework, regardless of whether banking establishments or non-banking foundations should moderate, assembling assets from financial backers and making them available to borrowers in the most efficient and cost-effective manner. 


\section{Statement of the Problem}

The job of capital market improvement in monetary development has in the previous many years pulled in critical consideration from money and advancement specialists and has additionally been the subject of scholastic discussion by analysts. This discussion presents its structure in four principle hypothetical suggestions which incorporate the stockpile driving speculation (McKinnon, 1973; Shaw, 1973; Islam, 2017, Alhassan \& Islam, 2019, Barghouthi, \& Islam, 2020, Baqir, Hussain, Islam, \& Waseem, 2020, Barakat, Perez, Ariza, Barghouthi, \& Islam, 2020, Neusser \& Kugler, 1998, Rahman et al., 2021), request pulling theory (Robinson, 1952; Patrick, 1966; Ireland, 1994), the endogenous development hypothesis (Greenwood \& Smith, 1997; Blackburn \& Hung, 1998) and the Stern-Lucas recommendation (Kuznets, 1955; Meir \& Seers, 1984; Lucas, 1988; Stern, 1989). To make for a sound and energetic monetary framework, certain monetary changes had in one time or the other been started by various systems in Nigeria. In 1987 for example, as a feature of the Structural Adjustment Porgramme (SAP) which incorporates the liberation of the unfamiliar trade market, financing costs, legitimization of credit controls, permitting of new banks just as institutional and administrative changes were done (Ikhide \& Alawode, 2002, Shahriar et al., 2021). As of late, more broad monetary changes have been started which incorporates the rebuilding of benefits reserve organization in 2004, bank recapitalization and solidification strategy in 2005 , protection recapitalization and rebuilding in 2007, presentation of miniature money banks just as capital market changes. These monetary changes were relied upon to achieve an effective monetary framework that would energize home-grown reserve funds and ventures and subsequently lead to financial development and improvement. These assumptions, be that as it may, is by all accounts unrealistic proved by decreasing monetary files including the new financial downturn being capable by the country. Adeoye \& Adewuyi (2005) laid confidence to this attestation by recognizing that the significant concern now in Nigeria is that monetary foundations (for the most part banks) appear to be not to have performed to assumptions as far as assembling reserve funds for financing long haul improvement projects in the genuine area. Some previous examines took on either hypotheses or techniques that overlook a portion of the immediate (credit supply and wide cash supply) and backhanded (market capitalization) channel(s), or models that disregard the short-run impacts. The Nigerian economy has not experienced great execution like the fascination of unfamiliar ventures and stop capital flight. The financial area appears to be not to have put forth a critical attempt intending to the monetary holes in the framework. This is apparent to the way that neither home-grown reserve funds nor interests in the nation have expanded obviously as the area remained generally oligopolistic and uncompetitive, with few huge banks controlling the more prominent section of the market as far as all-out resources, absolute liabilities, and complete credit in the financial framework. It becomes basic consequently to find out the adequacy of these changes by taking a gander at the impacts they have made as far as adding to monetary development.

Curiously, explicit examinations on the capital market improvement development nexus in Nigeria are as yet damaged with significant debates going from clashing outcomes to improper philosophies which makes for the trickiness of the outcomes. It is against these sceneries that this examination looks to research the connection between capital market improvement and monetary development in Nigeria utilizing quarterly information for the period (1981Q1-2017Q4) which gives a more extensive scope of perceptions and a more solid outcome dependent on a bigger number of perceptions which is deficient in different investigations. The examination takes on a Vector Autoregressive (VAR) and Vector Error Correction (VECM) system. The upsides of 
these strategies are that it makes it conceivable to recognize the short-run and since quite a while ago run causality if the factors are co-coordinated and limit the issue of endogeneity since it regards all factors as possibly endogenous. At long last, it demonstrates connections among macroeconomic factors in a unique way since it is entirely expected for macroeconomic factors to be influenced by their previous qualities. Along these lines, it empowers us to study the effect of unexpected shocks on endogenous factors (drive reaction capacities). The overall significance of every factor in clarifying the varieties in the endogenous factors can likewise be inspected (difference decay investigation).

Thus, the reason for the examination is to assess the connection between capital market advancement and financial development in Nigeria. This prompts the investigation theory stated in null form:

\section{Objectives of the Study}

The objectives of this study include (1) To determine the relationship between the volume of stock ratio and economic growth in Nigeria. (2) To determine the relationship between market capitalization ratio and economic growth in Nigeria. (3) To determine the relationship between banking system capitalization ratio and economic growth in Nigeria. (4) To determine the relationship between insurance capitalization ratio and economic growth in Nigeria.

\section{Research Questions}

The research questions for this study include (1) To what extent can the relationship between the volume of stock ratio and economic growth in Nigeria be determined? (2) To what extent can the relationship between market capitalization ratio and economic growth in Nigeria be determined? (3) To what extent can the relationship between banking system capitalization ratio and economic growth in Nigeria be determined? (4) To what extent can the relationship between insurance capitalization ratio and economic growth in Nigeria be determined?

\section{Research Hypotheses}

Ho1: There is no significant relationship between the volume of stock ratio and economic growth in Nigeria.

Ho2: There is no significant relationship between market capitalization ratio and economic growth in Nigeria.

Ho3: There is no significant relationship between the banking system capitalization ratio and economic growth in Nigeria.

Ho4: There is no significant relationship between insurance capitalization ratio and economic growth in Nigeria.

\section{LITERATURE REVIEW}

\section{Conceptual Framework}

\section{Concept of Economic Growth}

Economic development can be viewed as the increment in the limit of an economy to deliver labor and products throughout some undefined time frame. It is achieved by the increment in the useful limit of a country. In the perspectives of Antwi, Mills, and Zhao (2013), monetary development can be characterized as the development in a country's genuine GDP (an increment 
in a country's yield of labor and products) or the actual extension of the country's economy. Financial development can likewise be clarified as a positive change in the yield of a country's assembling labor and products which stretch throughout a specific timeframe. Being a total proportion of absolute monetary creation of a country, it along these lines address the market worth of every single last great and administration including individual utilization, private inventories, the government buys, paid-in development costs just as unfamiliar exchange adjusts. The most satisfactory proportion of financial development is the Real Gross Domestic Product (RGDP) which is considered as the broadest marker of monetary yield and development. It is intended to gauge the worth of the creation of those exercises which fall inside the limit of the public bookkeeping framework. Gross domestic product estimates financial development in money-related terms. The gross domestic product can be communicated either in ostensible terms which incorporate expansion or in genuine terms which adapt for swelling. Transient GDP addresses the yearly rate change in genuine public yield, while Long term GDP addresses the expansion in a pattern or expected GDP. In near examinations including various nations of various populace sizes, GDP per capita is commonly used.

\section{Capital Market Development and Economic Growth}

The capital market will be market fundamentally for long-haul speculation capital. It is a profoundly particular and coordinated monetary market and a fundamental instrument of financial development inferable from its capacity to assist and assemble investment funds and speculation. Anyanwu (1993) declares that generally, the positive connection between capital collection genuine monetary developments has for quite some time been avowed in financial theories. Attainment in capital amassing and activation for formative purposes differ among countries, yet it is for the most part subject to home-grown reserve funds and of unfamiliar capital inflows. As an outcome, to capture the risks of the current financial plunge, endeavors should be directed towards compelling asset assembly. It is in acknowledgment of this that contemplation is given to quantify for the advancement of the capital market as an establishment situated for the preparation of money from the excess financial units to the shortfall monetary units.

Essentially all aspects of human endeavor involve the utilization of cash which can either act naturally created or acquired. Cash helps capital amassing with an astounding returning impact on monetary development. In the capital market, the stock-in-exchange is cash that could be raised through a few instruments, under all-around regulated principles and guidelines, and clung to by different foundations or market administrators. It is verifiable that the pace of monetary development of any country is vaguely connected to the intricacy of its money market and precisely it's capital market effectiveness. Solid monetary business sectors help the countries of the world to assemble genuinely necessary monetary assets and abilities for development and advancement.

Value markets in non-industrial nations before the mid-1980s largely struggled with the old-style insufficiencies of bank controlled economies that were characterized by deficiency of value capital, not very adequate liquidity, nonappearance of unfamiliar institutional financial backers, and absence of financial backer's certitude in the securities exchange (Adebiyi, 2005). Monetary business sectors and their sub-unit, capital market are organized at whatever point members, with the assistance of courses of action, innovation, and different plans to work with the preparation and directing of assets into useful ventures. The noticeable quality of the capital market lies in its monetary intermediation capacity to connect the shortage units with the excess 
units of the economy. The shortfall of such a limit denies the economy of speculation and creation of labor and products for the cultural turn of events. Assets could along these lines be inactive toward one side while being needed at the opposite end looking for financial development and advancement (Akinbohungbe, 1996).

The Nigerian capital market like some other capital market on the planet gives the needed palliative that continues to spin the wheels of the economy towards development and improvement. It doesn't just give the assets expected to speculations yet in addition resourcefully apportions these assets to ventures of best returns. This allotment work is vital in finding out the general development of the economy. The working of the capital market influences liquidity, procurement of data about firms, hazard enhancement, investment funds activation, and corporate control (Anyanwu, 1993). To this end, by shifting the nature of these administrations, the working of financial exchanges can hamper the pace of monetary development (Equakun 2005). Okereke (2000) believes that the modest wellspring of assets from the capital market stays a significant component in the maintainable improvement of the economy and continued by identifying the upsides of capital market financing to incorporate longer repayment period as assets are held for medium and long haul period or in interminability, assets to state and neighbourhood government absent a lot of weights and adequate opportunity to reimburse loans.

\section{Theoretical Review Market-Based System Theory}

The case for a market-based framework tries to offer a response that spotlights the issues made by predominant banks. Bank-based frameworks frequently include delegates with a huge impact on firms and this impact might introduce itself contrarily. For instance, when banks acquire significant, inside data on firms, they can remove rents from firms by making firms pay for their more prominent admittance to capital. Hellwig (1991) in his perspective expressed that as far as new speculations or obligation renegotiations, manages an account with impact can get a greater amount of the normal future benefits from the firm than in a market-based framework. This capacity thusly to separate piece of the normal result to possibly productive speculations might decrease the endeavors reached out by firms to leave on creative, financially practical ventures (Rajan, 1992). In addition, Boot and Thakor (2000) displayed in their model, the likely strains between bank-based frameworks described by close connections among banks and firms and the advancement of dynamic protections markets. Banks being obligation guarantors likewise have the inborn inclination for reasonability, implying that bank-based frameworks might impasse corporate development and monetary development as indicated by the perspectives on (Morck and Nakamura, 1999). Weinstein and Yafeh (1998) discovered proof of this in Japan. In as much as firms with close connections to a "primary bank" have better admittance to capital and are less money caught than firms without a fundamental bank, the main bank firms watch out for (I) take on traditionalist, slow development systems along these lines do not develop faster than firms without a "principle bank," (ii) take part in more capital serious practices than non-primary bank firms holding different components steady, and (iii) create lower benefits, which is predictable with the powerful banks pulling out rents from the relationship. Allen and Gale (2000) further note that regardless of whether banks might be powerful at getting rid of duplication of data assortment and preparing, which is probably going to be valuable when individuals concur the sort of data to be assembled and how it ought to be handled, banks might not be compelling in non-standard conditions. Accordingly, banks may not be successful gatherers and processors of data in new, unsure circumstances containing imaginative items and processes (Allen and Gale, 
1999). In s comparable case, yet in a model of advance renegotiations, Dewatripont and Maskin (1995) exhibited that in a bank-based framework known since a long time ago run connections among banks and firms, banks will experience issues with the responsibility of not reworking contracts. On the other hand, more disconnected financial frameworks can all the more effectively make responsibilities to forcing stricter budgetary limitations. The earnest inconvenience of severe budgetary limitations might be essential for the financing of more current, higher-hazard firms. Appropriately, concentrated banks might be more useful in the subsidizing of developing, safer firms, while more market-based frameworks, as these theories suggest, will all the more effectively support the development of fresher, more hazardous enterprises.

A different line of assault on the adequacy of bank-based frameworks has to do with their job in exercising corporate power over firms just as the corporate administration of banks themselves. Bankers act in their wellbeing, not basically to the greatest advantage of all lenders or society everywhere, suggesting that brokers might contrive with firms against different leasers. For example, powerful banks might keep outcasts from eliminating inept supervisors if these managers are essentially liberal to the financiers (Black \& Moersch, 1998, Kader et al., 2021). Relating the German experience, Wenger, and Kaserer (1998) set that bank supervisors are amazingly incredible. They don't just apply corporate control over firms that get from being enormous banks to those organizations, yet additionally, vote the portions of a bigger number of little investors. For instance, in 1992, bank directors practiced on normal $61 \%$ of the democratic privileges of the 24 biggest organizations, and in 11 of these 24 biggest organizations, the offer was higher than $75 \%$. This control of organizations by bank management spreads even to the actual banks. In one of the investor gatherings of the three largest German banks, the level of intermediary votes was higher than $80 \%$, quite a bit of which was cast a ballot by the banks themselves (Wenger and Kaserer operation cit.) For example, Deutsche Bank held democratic rights for $47 \%$ of its offers, while Dresdner held democratic rights for $59 \%$ of its offers (Charkham, 1994). Thus, the administration of the bank has rested control of the banks from the proprietors of the banks and employs a huge influence on the nation's large companies. Wenger and Kaserer (1998) likewise showed cases in which the record of firms was distorted by banks to the general population and methodically fail to discipline the board. Additionally, Rajan and Zingales (2002) fight that in reacting to unfavorable shocks that influence the economy haphazardly, market-based frameworks will better identify, isolate, and bankrupt firms that are genuinely bothered and prevent them from harming the economy in entirety than a bank-based framework. In a bank-based (relationship-based) framework, bank directors might be to some degree reluctant to bankrupt firms with whom they have had long haul and conceivably multidimensional ties. While this might smooth transitory total shocks, it might likewise impede the effective acclimation to underlying changes. Thus in this manner, to the point that banks genuinely debilitate the corporate administration of firms, bank-based frameworks are believed to address a close to ideal component for control of firms and improvement of asset allocation. Likewise, depending on a bank-based monetary framework might represent a few issues because of the inconveniences in overseeing banks themselves (Caprio \& Levine, 2002). Furfine (2001) and Morgan (2002) see that while as yet being subject to debate, numerous scientists have contended that data deviations between bank insiders and untouchables are bigger than with nonmonetary companies. Under these conditions, it will be an undeniably challenging assignment for diffuse value and obligation holders to screen and control bank insiders. The governance issue which contributors frequently face has deteriorated within the sight of store protection. 
Besides, more noteworthy impenetrability recommends significantly more prominent intricacies recorded as hard copy impetus agreements to align administrative motivating forces with bank investor's holders and leasers. Perhaps on account of the especially extreme educational boundaries to overseeing banks, banks even have more inclination than non-monetary organizations to have enormous, controlling possession (Caprio, Laeven, \& Levine, 2003, Rahman et al., 2021, Shahriar et al., 2021). This convergence of proprietorship in combined with more noteworthy thickness may make it simpler for bank insiders to take advantage of different financial backers in the bank and the public authority if it is giving store protection. Mexico is packed with situations where amazing families utilize their power over banks to take advantage of different lenders and citizens (Haber, 2004; Maurer, \& Haber, 2004). For instance, La Porta, Lopez-de-Silanes, and Zamarripa (2003) tracked down an exceptionally high pace of associated loaning in Mexico. They tracked down that $20 \%$ of complete credits go to related parties. These advances anyway profited from financing costs that were around 415-420 premise points below those that were given to random gatherings. Related borrowers likewise profited from longer development periods, and were fundamentally less inclined to try and give guarantee protections. Notwithstanding every one of these, $33 \%$ were less inclined to repay the advances, and the recovery rates on these advances were around $78 \%$ lower than on credits to irrelevant gatherings. Likewise, Laeven (2001) provides evidence that insiders in Russian banks redirected the course of advances to themselves and afterward defaulted $71 \%$ of the time.

Defenders of market-based monetary frameworks declare that markets give a superior offset of hazard the board devices that consider more noteworthy customization of hazard upgrading instruments. Despite the way that bank-based frameworks give less expensive, essential danger to the executive's administrations for normalized circumstances, market-based frameworks give more prominent adaptability to make items to particulars. Thus, as economies create and need a more extravagant arrangement of hazard the board instruments and means for raising capital, they may close by advantage from a lawful and administrative climate that upholds the advancement of market-based exercises, or in general development might be retarded.

\section{Financial Service Theory}

This theory was made popular by Levine in 2002. The financial services view stress the role of banks and markets in research firms, exerting corporate control, creating risk management devices, and mobilizing society's savings for the most productive endeavors. This view minimizes the bank-based versus market-based debate and emphasizes the quality of financial services produced by the entire financial system.

\section{Empirical Review}

Nwokoma (2002) looks at the connection between the securities exchange and some macroeconomic markers. The investigation result uncovers that lone mechanical creation and level of loan costs, as addressed by the 3-month business bank store rate have a since quite a while ago run relationship with the financial exchange. The study also discovered that the Nigerian market reacts more to its past costs than changes in the macroeconomic factors in the short run.

Ibrahim and Aziz (2003) examine the connection between stock costs and mechanical creation, cash supply, customer value file, and conversion standard in Malaysia. Stock costs are found to impart positive long-haul connections to mechanical creation and Consumer Price Index 
(CPI). On the contradicting view, the examination tracked down that stock costs have a negative relationship with cash supply and conversion scale.

Carporale et al. (2004) look at the causal connection between securities exchange and financial development utilizing the vector auto-relapse (VAR) technique. The investigation utilized an example of seven nations, Argentina, Chile, Greece, Korea, Malaysia, the Philippines, and Portugal. The outcomes show that an all-around created securities exchange can advance since a long time ago run financial development.

In another investigation, Carporale et al. (2005) utilize the vector auto regression (VAR) structure to test the endogenous development speculation for four nations: Chile, South Korea, Malaysia, and the Philippines. The discoveries demonstrate that the causality between securities exchange parts, speculation, and monetary development is critical and is by the endogenous development model. The investigation likewise reveals that the degree of the venture is the channel through which securities exchanges upgrade monetary development over the long haul.

Adam and Sanni (2005) study the job of financial exchange in Nigeria's monetary development. The investigation utilized the Granger-Causality test and relapse examination. The outcomes revealed unidirectional causality among GDP growth and market capitalization and a bi-directional causality between GDP development and market turnover. The outcomes likewise uncover a positive and critical connection between GDP development turnover proportions. The examination prompted that administration ought to energize the advancement of the capital market since it has a positive relationship with monetary development.

Ted Arzarmi et al. (2005) examine the exact connection between securities exchange advancement and financial development in India. The study found no indication of a connection between the Indian financial exchange advancement and monetary development in the period under audit. While the examination discovered help for the meaning of financial exchange improvement in monetary advancement during pre-progression, they tracked down a negative connection between securities exchange improvement and financial improvement for the postprogression time frame.

Dritsaki and Dritsaki-Bargiota (2005) utilize a tri-variate VAR model to contemplate the causal connection between stock, credit market, and monetary development for Greece. Utilizing month-to-month information covering the period 1988:1-2002:12, the outcomes uncover unidirectional causality moving from financial improvement to securities exchange and bidirectional causality between monetary turns of events and the financial area. The study institutes no causal connection between financial exchange capacity and banking area.

Elumilade and Asaolu (2006) study the connections between securities exchange capitalization rate and loan cost. The examination utilized a period series information for the period 1981-2000from the Central Bank of Nigeria (CBN) and Nigeria Stock Exchange (NSE) using relapse. The examination results show that the overarching financing cost uses beneficial outcomes on securities exchange capitalization rate. Government improvement stock rate practices adverse consequence on stock market capitalization rate and the overarching financing cost applies the negative effect on government development stock rate. The investigation further recommends data as vital to capital market improvement.

The investigation consequently suggests that the administrators of the Nigerian capital market should raise the degree of mindfulness so financial backers will be fully informed regarding the happenings in the market. 


\section{Research Design}

\section{RESEARCH METHODS}

This study uses an ex-post facto research design approach for the data analysis. This approach combines theoretical consideration (a prior criterion) with empirical observation and extracts maximum information from the available data. It enables us therefore to observe the effects of explanatory variables on the dependent variables.

\section{Nature/Sources of Data}

To investigate the effects of capital market development on economic growth in Nigeria, secondary data consisting of quarterly time series data are used covering the period from 1981Q1 to 2017Q4. Thus, the data consisting of a total of 148 observations is considered rich enough to yield reliable results. The data which are all sourced from secondary sources from the Central Bank of Nigeria database will be presented in tables in chapter four.

\section{Method of Data Analysis}

The popular vector autoregressive (VAR) methodology is employed. VAR models are most suitable for modelling the dynamic behaviour of most macroeconomic and financial time series data. It is also used for forecasting (Ouliaris, Pagan, \& Restrepo, 2016). The use of VAR as a modelling system of autoregressive time series has several advantages which include its flexible nature (Brooks, 2008), forecast generated is highly reliable (Ouliaris, Pagan, \& Restrepo, 2016), and VAR models provide a window for analysing causal impacts of policy shocks through impulse response function, variance decomposition, and Granger causality. This is consistent with the aim of this study which is to examine the effect of capital market development on economic growth.

\section{Empirical Model Specification}

$R G D P G=f(V O S R, M C A P, B S C A P, I N S C A P)$

Where;

$R G D P G=$ Real Gross Domestic Product Growth Rate

$V O S R=$ Value of Stock Ratio to GDP

$M C A P=$ Market Capitalization ratio to GDP

$B S C A P=$ Banking System Capitalization Ratio to Market Capitalization

INSCAP = Insurance Capitalization Ratio to Market Capitalization

\section{Apriori Expectations}

\section{$R G D P G=f(V O S R, M C A P, B S C A P, I N S C A P)$}

Volume of stocks ratio to GDP, market capitalization, banking sector capitalization, and insurance sector capitalization to real GDP all are measures of capital market development and 
financial sector deepening and are expected to relate positively to real economic performance and growth.

The econometric representations of the above functional model is given by:

VAR

Model:

$R G D P G_{t}=\lambda_{01}+\lambda_{11} R G D P G_{t-1}+\lambda_{21} \operatorname{VOSR}_{t-1}+\lambda_{31}$ MCAP $_{t-1}+\lambda_{41}$ BSCAP $_{t-1}+$

$\lambda_{51}$ INSCAP $P_{t-1}+v_{1 t}$

$\operatorname{VOSR}_{t}=\lambda_{02}+\lambda_{12}$ RGDPG $_{t-1}+\lambda_{22} \operatorname{VOSR}_{t-1}+\lambda_{32}$ MCAP $_{t-1}+\lambda_{42}$ BSCAP $_{t-1}+$ $\lambda_{52} I N S C A P_{t-1}+v_{2 t}$

$M C A P_{t}=\lambda_{03}+\lambda_{13} R_{G D P G}+1+\lambda_{23} \operatorname{VOSR}_{t-1}+\lambda_{33} M$ CAP $_{t-1}+\lambda_{43}$ BSCAP $_{t-1}+$ $\lambda_{53} I N S C A P_{t-1}+v_{3 t}$

BSCAP $_{t}=\lambda_{04}+\lambda_{14} R G D P G_{t-1}+\lambda_{24} \operatorname{VOSR}_{t-1}+\lambda_{34} M C A P_{t-1}+\lambda_{44}$ BSCAP $_{t-1}+$ $\lambda_{54} I_{\text {NSCAP }}+1+v_{4 t}$

\section{RESULTS AND DISCUSSION}

\section{Descriptive Analysis}

\section{Growth Rate in Real Gross Domestic Product}

Figure 4.1 shows the time series graph for quarterly real GDP growth rate from 1981Q1 to 2017 Q4.

RGDPG

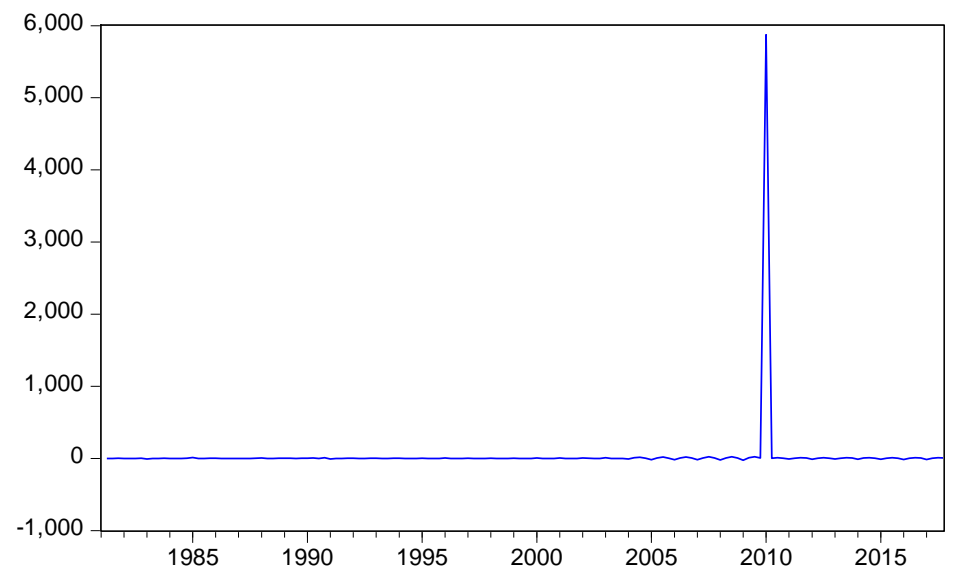

Figure 4.1: The time series plot of quarterly real GDP growth rate (1981Q1 - 2017Q4) Source: EViews output based on Research Data 
From figure 4.1, apart from the obvious outlying observation in 2010Q1, which is due to the economic rebasing in Nigeria that took effect from that quarter, all other observations stayed around their mean value over the study period? Thus, as expected, the real GDP growth rate series is stationary. The implication is that any growth model that fails to incorporate or control for the effect of this structural break would suffer model misspecification bias, which would also lead to unreliable results and spurious conclusions. Therefore, to capture the effect of this disturbing observation, all our economic growth models would include a dummy variable that takes the value 1 for 2010Q1 observation, or 0 otherwise.

Tables 4.1 presents the descriptive statistics for two sample variants for real GDP growth rate; a sample that includes all observations and a sample that excludes the outlying observation. We report the statistics for the two samples to underscore the importance of the economic rebasing exercise that took effect from the first quarter of 2010 in Nigeria, which is a milestone for this study.

Table 4.1: Descriptive statistics for real GDP growth rate series (1981Q1 - 2017Q4)

\begin{tabular}{|l|l|l|}
\hline Statistic & Sample with outlier & Sample without outlier \\
\hline $\bar{x}$ & 41.30542 & 1.348268 \\
\hline Max & 5875.050 & 21.75271 \\
\hline Min & -23.72240 & -23.72240 \\
\hline$\sigma$ & 484.5058 & 7.055771 \\
\hline$S$ & 11.99644 & -0.459365 \\
\hline K & 144.9458 & 6.329684 \\
\hline IB & 126936.1 & 72.57941 \\
\hline p-value (JB) & 0.000000 & 0.000000 \\
\hline
\end{tabular}

Source: EViews output based on research data

From table 4.1, we can also see that the effect of the structural break on the growth rate series is evident, with the difference in the key summary statistics between the two sample variants being quite substantial. Specifically, for the sample with outlier, it is obvious that the average growth rate in real GDP of $41.30 \%$, with a standard deviation of $484.50 \%$ and a maximum of $5875 \%$ does not reflect the economic reality in Nigeria. On the contrary, however, the average quarterly GDP growth rate of $1.34 \%$, with a standard deviation of $7.05 \%$ and a maximum of $21.75 \%$ truly reflects the economic reality in Nigeria. Further, while the sample with an outlier has a large positive skewness coefficient $(S=11.99)$, the sample without the outlying observation has a small negative skewness coefficient $(S=-0.45)$. Although, both samples have an excess kurtosis $(K-3>0)$ and consist of observations that are not normally distributed ( $p$-value $(J B)=0.0000$ ), the large difference in the kurtosis values of the two samples show that the sample with the outlying observation contains more data extremes than the 
sample without the outlying observations. Thus, as stated earlier, these results imply that any GDP growth model that omits the effect of this observed structural break would suffer

\section{Capital Market Development}

Figure 4.2 shows the time-series graph for the value of traded stocks ratio to GDP, market capitalization ratio to GDP, and prime lending rate, all in logarithmic form, from 1981Q1 to 2017 Q4.
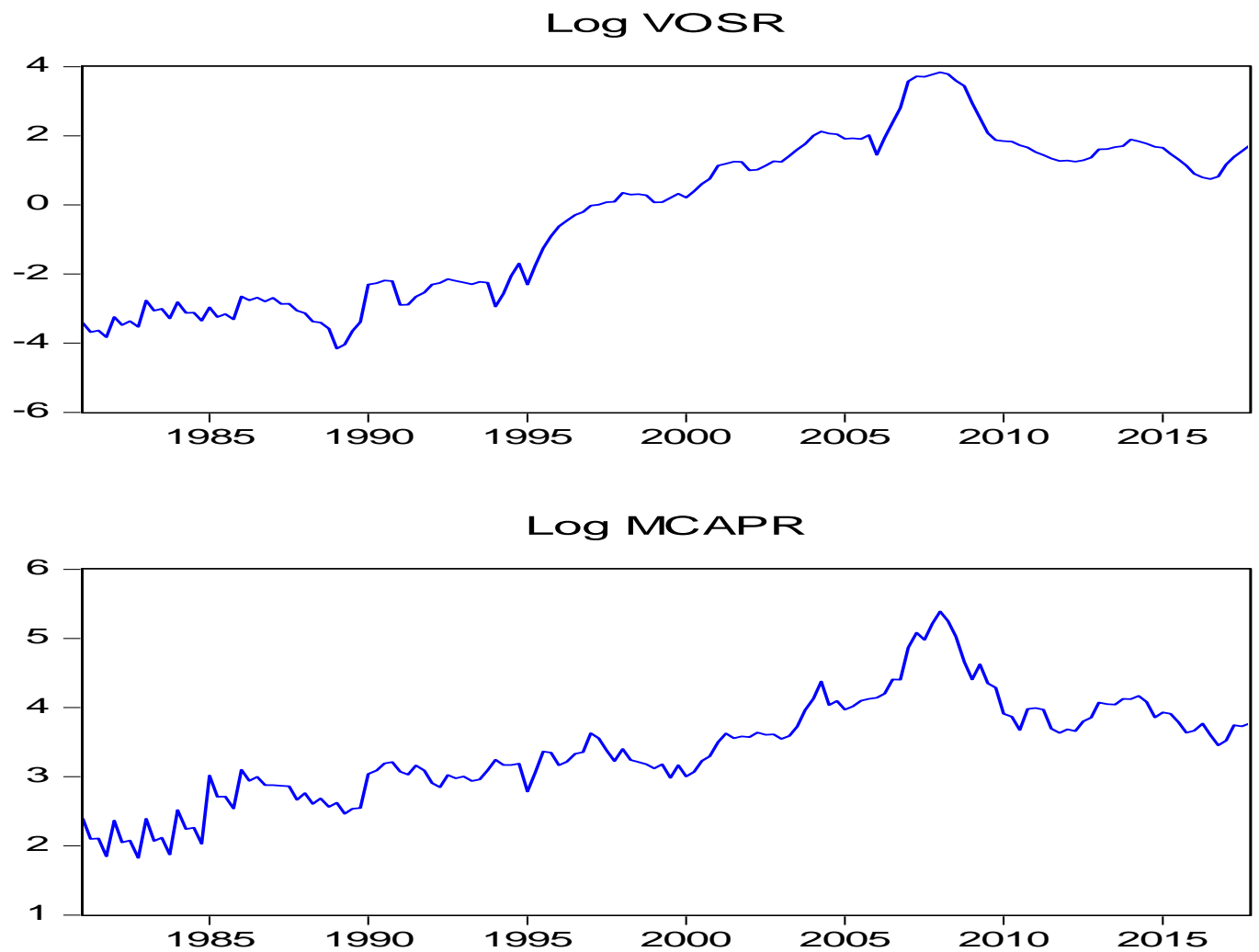

Log intr

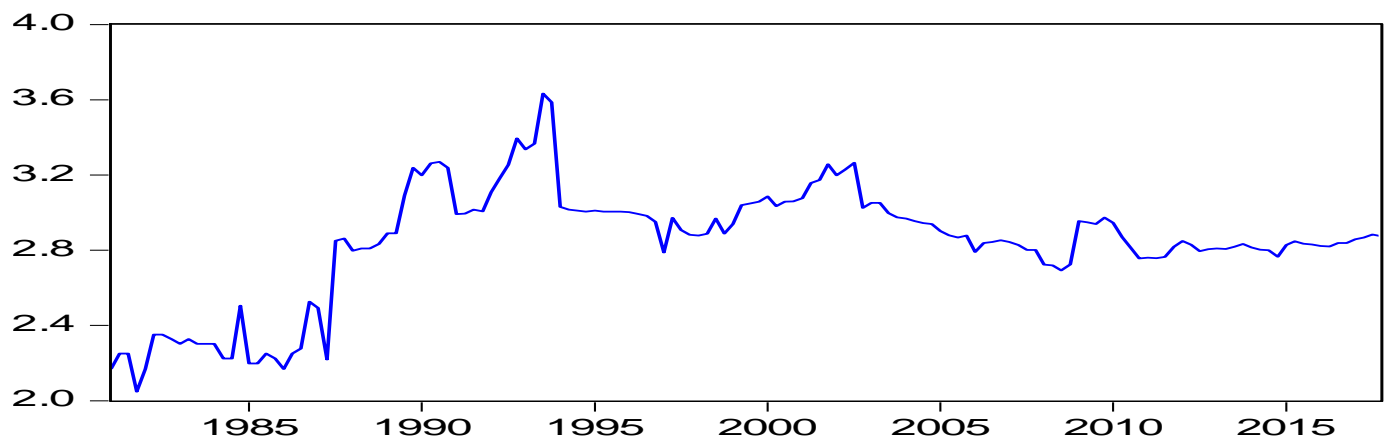

Figure 4.2: The time series plots of the log of VOSR, MCAPR, and BSCAP (1981Q1 2017Q4)

Source: EViews output based on Research Data 
From figure 4.2, all the variables trended upward but like a random walk over the sample period. Thus, they seem to be non-stationary.

Table 4.2 shows the descriptive statistics for VOSR, MCAPR, and BSCAP.

Table 4.2: Descriptive statistics for VOSR, MCAPR, and BSCAP (1981Q1 - 2017Q4)

\begin{tabular}{|l|l|l|l|}
\hline Statistic & VOSR & MCAPR & BSCAP \\
\hline $\bar{x}$ & 4.576913 & 39.69264 & 17.85878 \\
\hline Max & 46.53229 & 219.0386 & 37.80000 \\
\hline Min & 0.015672 & 6.207219 & 7.750000 \\
\hline$\sigma$ & 9.114465 & 35.69840 & 5.146223 \\
\hline S & 3.338962 & 2.615844 & 0.494034 \\
\hline K & 13.74765 & 11.11065 & 4.680818 \\
\hline IB & 987.3240 & 574.4443 & 23.44212 \\
\hline p-value (JB) & 0.000000 & 0.000000 & 0.000008 \\
\hline
\end{tabular}

\section{Source: EViews output based on research data}

From table 4.2, the market capitalization ratio is $39.69 \%$ while the value of traded stocks ratio and interest rate have a mean of $4.57 \%$ and $17.85 \%$ respectively. The three variables all have high variability, with MCAPR $(\sigma=35.69)$ being the most volatile. Further, all variables have a positively skewed $(S>0)$ and leptokurtic distribution $(K>3)$, but both skewness and kurtosis coefficients are highest for VOSR $(S=3.33, K=13.74)$. The JB statistic (p-value < 0.01 ) also strongly rejects the assumption that the series have a normal distribution. Thus, the capital market development variables would enter our growth model in logarithmic form for a more reliable empirical outcome.

\section{Estimation and Analysis of Empirical Model Stationarity test for the Model}

The model seeks to establish whether economic growth in Nigeria can be explained by capital market development measured by the value of stocks traded in the stock market and equity market capitalization, both expressed as a ratio of nominal GDP. We also include interest rate as a controlling factor in this model. The results of the ADF test for these variables are presented in table 4.3. 
Table 4.3: ADF tests for the RHS variables in the model

\begin{tabular}{|l|l|l|ll|}
\hline \multirow{3}{*}{ Variable } & \multicolumn{2}{|l|}{ tau-statistic } & & \\
\cline { 2 - 5 } & Level & First difference & Conclusion & \\
\hline LVOSR & -1.4385 & -10.8110 & Difference & Stationary \\
& $(0.1398)$ & $(0.0000)$ & I $(1)$ & \\
\hline LMCAPR & -2.7952 & -4.8242 & Difference & Stationary \\
& $(0.2015)$ & $(0.0007)$ & I(1) & \\
\hline LBSCAP & -2.7160 & -11.4739 & Level & Stationary \\
& $(0.0737)$ & $(0.0000)$ & I $(1)$ & \\
\hline
\end{tabular}

Source: EViews output based on research data; parenthesis contains p-values

From table 4.3, the ADF tau-statistic for the test on level data has a probability of 0.1526 for LCLRR, 0.2015 for LMCAPR, and 0.0737 for LBSCAP, indicating that the test is insignificant in all cases. However, the test is significant at a 10\% level for LBSCAP. On the contrary, however, the test is highly significant (p-value $<0.001$ ) in all its applications for first difference data. Therefore, the assumption that series contains unit root is supported for each variable at level data but fails when the first difference of the data is considered. In other words, all variables are I(1). These results imply that all endogenous variables in model 5 would be modelled in the first difference form, except RGDPG.

\section{Reduced Form VAR Estimation for the Model}

Tables 4.4 and 4.5 present the VAR lag length selection and the residual diagnostic test for reduced form VAR for the empirical model. The VAR order selection is based on AIC, SIC, and the likelihood ratio (LR) test at 5\% significance level. For both AIC and SIC, the decision rule is to select the lag order that corresponds to their minimum values, while the decision rule for LR test is to select the lag order that maximizes the test value. Also, a rebase dummy variable, DUMREBASE, is included in the model to capture the effect of the structural break observed in the first quarter of 2010 real GDP growth plot in figure 2. Further, as in the previous cases, we report the reduced form VAR estimation results for model 5 in the Appendix, since it is not easy to interpret, due to too many lags that are included.

Table 4.4: VAR order selection for the model

\begin{tabular}{|l|l|l|l|}
\hline Lag & LR & AIC & SIC \\
\hline 0 & NA & $4.369412^{*}$ & $4.538302^{*}$ \\
\hline 1 & 26.49452 & 4.400420 & 4.907092 \\
\hline 2 & 29.12763 & 4.404841 & 5.249294 \\
\hline 3 & 26.78506 & 4.420776 & 5.603010 \\
\hline 4 & $32.49611^{*}$ & 4.382429 & 5.902444 \\
\hline 5 & 12.90555 & 4.502341 & 6.360137 \\
\hline 6 & 15.44016 & 4.595918 & 6.791496 \\
\hline 7 & 20.41815 & 4.638812 & 7.172170 \\
\hline 8 & 14.61315 & 4.729855 & 7.600995 \\
\hline
\end{tabular}

Source: EViews output based on research data; *indicates the selected lag order 
Table 4.5: VAR LM serial correlation test for the Model

\begin{tabular}{|l|l|}
\hline LM statistic & p-value \\
\hline 16.60928 & 0.4113 \\
\hline
\end{tabular}

Source: EViews output based on research data

Inverse Roots of AR Characteristic Polynomial

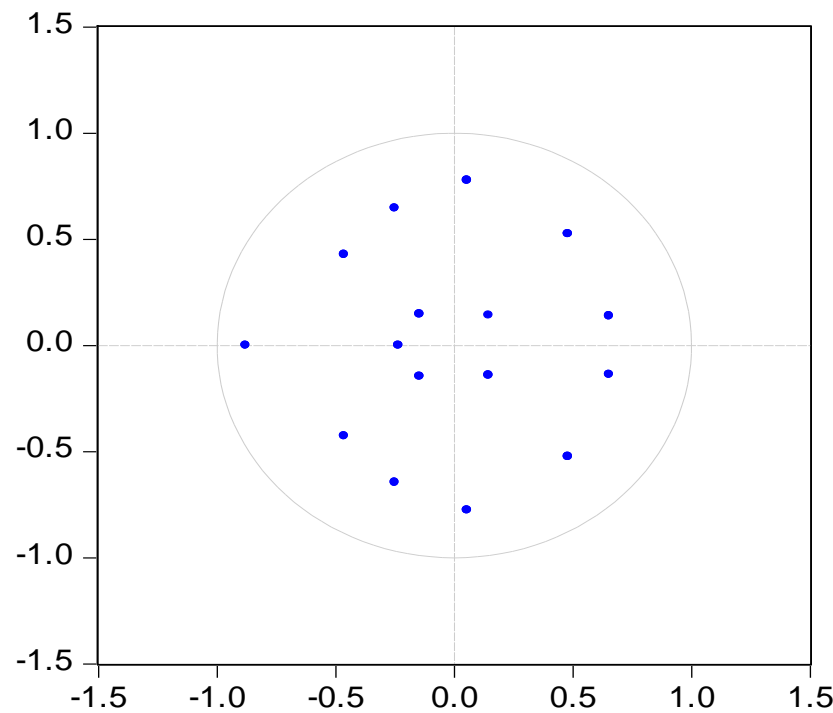

Figure 4.3: VAR roots plot in relation to the unit circle

From table 4.4, as indicated by the asterisk (*), while both AIC and SIC select a VAR with 1 lag, LR prefers a VAR with 4 lags. Therefore, we consider 4 lags as appropriate for our VAR specification for our empirical model.

From table 4.5 , the probability of the LM statistic is quite high at 0.4113 , indicating that the test is insignificant. Thus, we fail to reject the null hypothesis that the fitted VAR residuals are serially correlated and conclude that the fitted VAR (4) model is not wrongly parameterized. Figure 4.3, which plots the inverted roots of the estimated VAR(4) in relation to the unit circle, shows that all the roots lie inside the unit circle. Thus, the estimated coefficients are stable. This, therefore, implies that structural analysis can be conducted to meaningfully interpret the fitted $\mathrm{VAR}$ results and test the relevant hypotheses.

\section{Structural Analysis for the Model}

Figures 4.4 and 4.5 show the impulse response function (IRF) and variance decomposition for real GDP growth for the model. The IRF helps to evaluate the impact on the Nigerian economy of unexpected changes in the value of traded stock and market capitalization, both expressed as a ratio of nominal GDP. The impact of interest rate as the control factor is also examined. The variance decomposition shows the contribution of each of these factors to the variation in real gross domestic product. Again, six periods are used.

Table 4.6 shows the VAR Granger causality/blocked exogeneity Wald test for joint significance of lags of each endogenous variable in our estimated VAR(4) model. 
Response to Cholesky One S.D. Innovations \pm 2 S.E.

Response of RGDPG to RGDPG

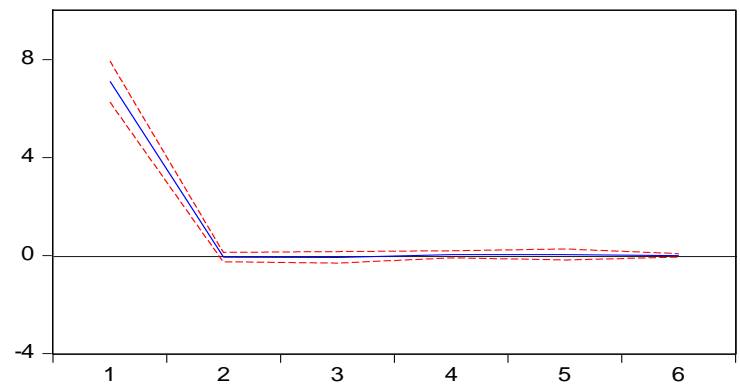

Response of RGDPG to D(LMCAPR)

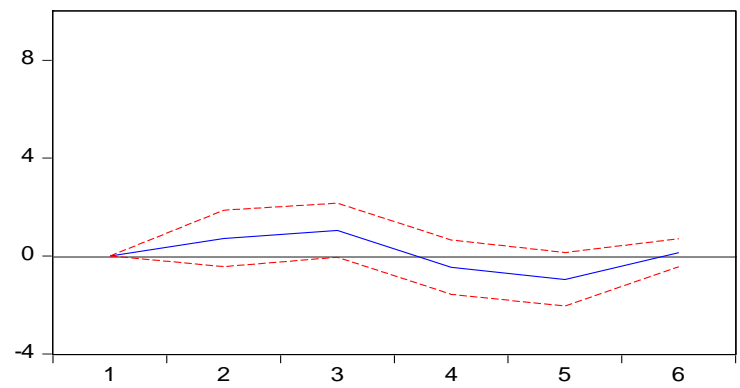

Response of RGDPG to D(LVOSR)

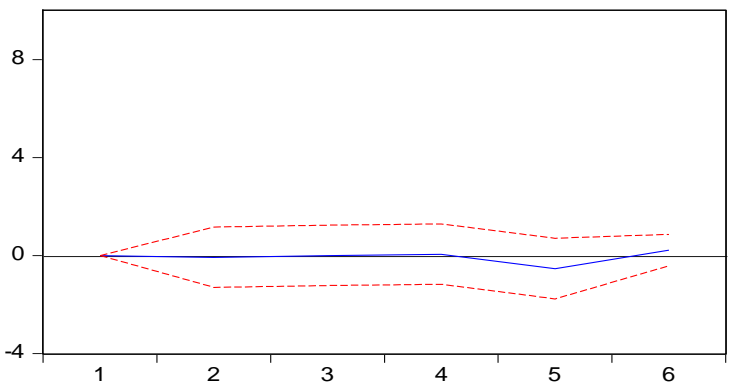

Response of RGDPG to D(LINTR)

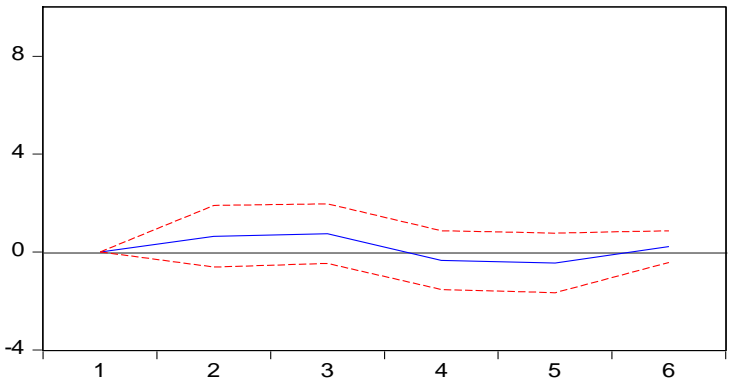

Figure 4.4: IRF for RGDPG for model 5

Variance Decomposition \pm 2 S.E.

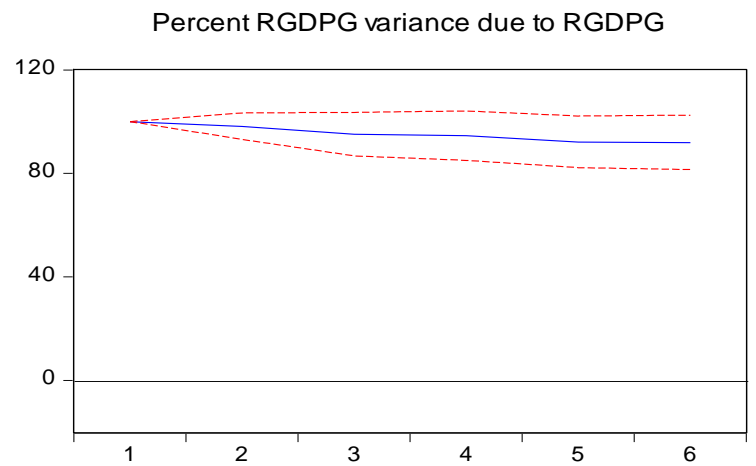

Percent RGDPG variance due to $\mathrm{D}$ (LVOSR)

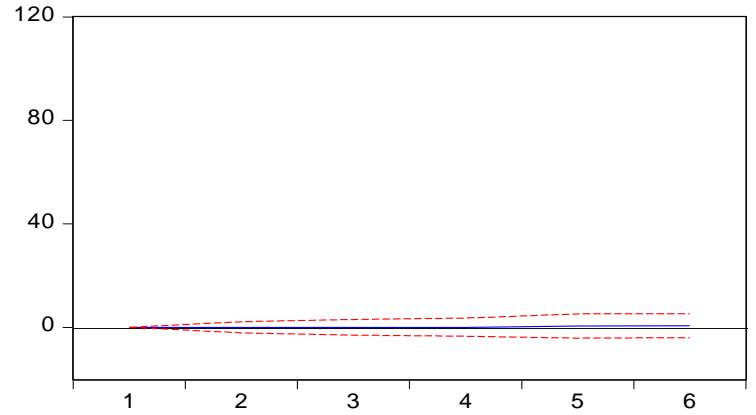

Percent RGDPG variance due to D(LMCAPR)

Percent RGDPG variance due to D(LBSCAP)
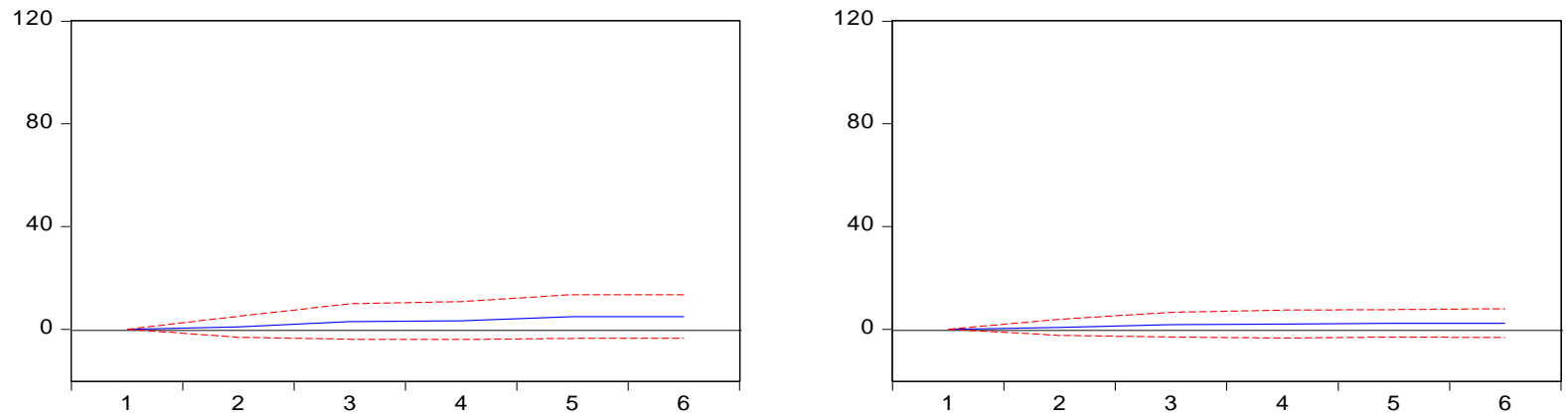

Figure 4.5: Variance decomposition of RGDPG for the model 
Table 4.6: VAR Granger causality Wald test for the model

\begin{tabular}{|l|l|l|}
\hline Excluded & Chi-sq. & p-value \\
\hline DLVOSR & 3.671182 & 0.4523 \\
\hline DLMCAPR & 11.61026 & 0.0205 \\
\hline DLBSCAP & 4.369447 & 0.3583 \\
\hline All & $\mathbf{1 3 . 8 7 2 9 3}$ & 0.3089 \\
\hline
\end{tabular}

\section{EViews output based on research data}

The impulse responses in figure 4.4 show that RGDPG initially responds positively to its own shock, but from the second period, the response becomes negative but very close to zero. While there is a small negative effect of an unexpected change in DLVOSR on RGDPG, the effects of unexpected changes in LDMCAPR and LDBSCAP are similar in both magnitude and direction, being positive for the first three quarters and negative afterward.

From figure 4.5, just as own shock is the main source of variation in real GDP growth in all previous cases, most of the variations in real GDP growth in the case of model 5 are also caused by its past shocks. Specifically, own past shock contributes almost all the error variance in real GDP growth in the second period while in the fourth and sixth periods, it contributes approximately $95 \%$ and $92 \%$ respectively. In the second period, the individual contributions of DLVOSR, DLMCAPR, and DLBSCAP to the variation in RGDPG are $0.01 \%, 0.99 \%$, and $0.78 \%$ respectively, while in the sixth period, the contributions are $0.62 \%, 5.01 \%$, and $2.41 \%$.

From table 4.6, the Wald test statistic is significant at 5\% level for DLMCAPR (p-value = 0.0205 ) but insignificant for both DLVOSR ( $\mathrm{p}$-value $=0.4523$ ) and DLBSCAP ( $\mathrm{p}$-value = 0.3583). This means that while the growth rate in real GDP is significantly affected by the exogenous shock to market capitalization ratio, which is a measure of capital market size, it is not significantly affected by changes in both values of stocks traded and interest rate. The combined effect of these variables on real GDP growth rate is statistically insignificant (Chi-sq. $=13.872, \mathrm{p}$-value $=0.3089$ )

\section{Testing of Hypothesis}

$\boldsymbol{H o}_{1}$ : There is no significant causal relationship between capital market development and economic growth in Nigeria

Here, capital market development is defined in terms of the combined effect of the value of traded stocks in the stock market, market capitalization, banking sector capitalization, and insurance capitalization represented by the variable "All" in table 4.6. Therefore, the associated p-value of the Wald (Chi-sq.) statistic corresponding to all would be used to test the above hypothesis. The chosen level of significance is $5 \%$.

If the p-value corresponding to all is less than 0.05 , then we would reject $\mathrm{Ho}_{5}$ and conclude that there is a significant causal relationship between capital market developments to economic growth in Nigeria. Otherwise, there would be no evidence against $\mathrm{Ho}_{5}$ it. 
From table 4.6, the probability of the Wald (Chi-sq.) statistic corresponding to All is 0.3089 which is higher than 0.05 , showing that the test is insignificant at a $5 \%$ percent level. We, therefore, fail to reject the above null hypothesis and conclude that capital market development has a causal impact on economic growth in Nigeria.

\section{Discussion of Findings}

The study found out that there is a weak causal impact on the economic growth of capital market development; measured by the joint influence of the value of traded stocks ratio to GDP, market capitalization ratio to GDP, with an interest rate as the control variable. However, individually, the effect of the market capitalization ratio is statistically significant.

Our hypothesis states that capital market development has no causal effect on economic growth in Nigeria. According to the market-based theory of financial development, the capital market, which is also a subset of the financial sector, provides financial resources directly to the productive sectors, and thus, is a significant factor for economic growth. Therefore, we expected a priori, a positive causal link from capital market development to economic growth. Contrary to this expectation, our results show that capital market development, measured by the conglomerate indicators of market liquidity and the market size has no explanatory power for economic growth. This insignificant relationship is evident from the results of the Granger causality Wald test in table 4.6 which shows that the lags of both values of traded stocks ratio to nominal GDP and market capitalization ratio to nominal GDP in the rate of growth model are jointly insignificant even at $10 \%$ level. Therefore, in disagreement with the market-based financial development theory, indicators of capital market activeness (liquidity) and market size jointly lack predictive power for economic growth in Nigeria. However, this lack of significance is mainly due to market illiquidity as the results in table 4.20 provides evidence that market size, measured by market capitalization ratio to nominal GDP, significantly enters the growth model at $5 \%$ level, while market liquidity, measured by the value of traded stocks ratio to nominal GDP, enters the model insignificantly, hence, the insignificance of their combined effect. Thus, while the market size can be treated as exogenous in the growth model, market liquidity remains endogenous.

In terms of the effect direction, the results suggest that market size and economic growth are positively related. The impulse response analysis in figure 4.32 shows that the real GDP growth rate responded positively to a one standard deviation shock to market capitalization ratio up to the third quarter, with a relatively large effect size. An increase in market size would increase the rate of growth in real GDP up to the third quarter. Further, as evident in figure 4.33, the proportion of the variation in the rate of growth in real GDP that is due to shock in market capitalization ratio is $0.99 \%$ in the second period, and approximately $5 \%$ in both fifth and sixth periods (quarters). Conversely, the contribution of the value of traded stocks ratio to the shock to the rate of growth in real GDP is around zero up to the sixth quarter. Therefore, irrespective of its size, the illiquidity of the Nigerian capital market makes it less active in driving economic growth. This finding is consistent with the recent explanation by Ms. Patience Oniha, the Director-General of the Debt Management Office (DMO). According to Vanguard Newspaper (2019, January 19), the DMO boss stated in an interview by News Agency of Nigeria that the significant decline in the level of subscription of Federal Government Bonds is largely due to the low level of liquidity in the financial system, which is, in turn, caused by the tight monetary policy stance of the Central Bank of Nigeria. The results, however, disagree with the previous results by Levine and Zervos (1998) and Ross (2002) that economic growth is significantly 
related to market liquidity but insignificantly related to market size. These findings also reflect the developmental stage of the Nigerian economy. According to Bollard, Hunt, and Hodgetts (2011), capital markets play a more active role in providing financial products and services for productive economic activities than banks in developed countries in emerging or developing countries. Thus, the lack of significance of the combined effects of market size and market liquidity is consistent with the view that the Nigerian economy is still at the developing stage.

\section{SUMMARY AND CONCLUSION}

This study presents an empirical examination of the causal effect of capital market development and economic growth using Nigerian data. The capital market-growth link has been well researched, but to date, no attempt has been made to provide a comprehensive analysis of this relationship from the perspective of a financial system that is still at the developing stage. Besides, what financial system is better (bank-based or market-based) and what drives financial development are empirical questions still begging for answers. For this reason, the researcher decided to provide further insights by specifying an empirical model focusing on capital market development.

The VAR framework was employed and an empirical model was specified. The specified models were estimated using the EViews software package version 9. Diagnostic tests were conducted on the estimated models and the hypotheses were tested. The hypotheses testing were based on the Block exogeneity Wald test, which tests the joint significance of the lags of all explanatory variables in the model to determine its causal impact on economic growth. Interestingly also, our findings show that the capital market is not the main driver of financial development and that irrespective of its size, the illiquidity of the Nigerian capital market makes it less active in driving economic growth.

When the model was estimated, the results show that although market size, measured by market capitalization ratio to GDP, enters the growth model positively and significantly, its combined effect with market liquidity, measured by the value of stock traded ratio to GDP, is however insignificant. Thus, we conclude that irrespective of its size, the illiquidity of the Nigerian capital market makes it less active in driving economic growth. We also conclude that the Nigerian capital market is still at the developing stage and requires more deepening in terms of liquidity in order to play its role in driving economic growth.

The results are robust and do not suffer from endogeneity or serial correlation problem as all the specification and diagnostic issues were addressed. Further, the study provides answers to all its questions and achieves all its objectives. Therefore, the motivation for conducting the study has been justified.

Securities and Exchange Commission should formulate and implement financial innovation practices in the capital market to position the sector for economic growth and stability.

\section{REFERENCES}

Adeoye, B. W. \& Adewuyi, A. O. (2005). Benefits and costs of financial sector reforms: Nigeria's experience. In: Cost and benefits of economic reforms in Nigeria. Selected Paper for the 2005 Annual Conference of the Nigeria Economic Society, 4(1), Chapter 16. 
Antwi, S.I., Mills, G.A., \& Zhao, X. (2013). Impact of FDI on economic growth: Empirical evidence from Ghana. International Journal of Academic Research, Finance and Management Sciences, 3(1), 18-25.

Allen, F., \& Gale, D. (2000). Comparing financial systems, Cambridge, MA: MIT Press

Allen, F., \& Gale, D. (1997). Financial markets, intermediaries, and inter-temporal smoothing. Journal of Political Economy, 105, 523-546.

Alhassan, I., \& Islam, K. M. A. (2019). The Impact of Environmental and Social Disclosures on the Financial Performance of Oil and Gas Companies in Nigeria. The Millennium University Journal, 4(1), 33-44. Retrieved from http://www.themillenniumuniversity.edu.bd/journal/index.php/TMUJ/article/view/28

Black, S. W., \& Moersch, M. (1998). Financial structure, investment and economic growth in OECD countries. In S.W. Black, \& M. Moersch, (Eds.), Competition and convergence in financial markets: The German and Anglo-American models. New York, North-Holland Press, 157-174.

Blackburn, K., \& Hung, V.T.Y. (1998). A theory of growth, financial development, and trade. Economica, 65, 107-24.

Barghouthi, O. A., \& Islam, K. M. A. (2020). Financial Stability Implications of Stress Testing for Risk Taking and Credit Growth. American Finance \& Banking Review, 5(2), 1-4. https://doi.org/10.46281/amfbr.v5i2.778

Boot, A.W. A., Greenbaum, S. J., \& Thakor, A. (1993). Reputation and discretion in financial contracting. American Economic Review, 83, 1165-1183.

Baqir, M., Hussain, S., Islam, K. M. A., \& Waseem, R. (2020). Comparison of Financial Performance of Private Commercial Banks in Pakistan. American Finance \& Banking Review, 5(2), 5-17. https://doi.org/10.46281/amfbr.v5i2.841

Barakat, F. S. Q., Perez, M. V. L., Ariza, L. R., Barghouthi, O. A., \& Islam, K. M. A. (2020). THE IMPACT CORPORATE GOVERNANCE ON INTERNET FINANCIAL REPORTING: EMPIRICAL EVIDENCE FROM PALESTINE. International Journal of Accounting \& Finance Review, 5(4), 1-22. https://doi.org/10.46281/ijafr.v5i4.852

Caprio Jr. G., \& Levine, R. (2002). Corporate governance in finance: Concepts and international observations. In R.E. Litan (Ed.), Financial sector governance: The roles of the public and private sectors

Charkham, J. (1994). Keeping good company: A study of corporate governance in five countries, Oxford, Clarendon Press.

Dewatripont, M., \& Maskin, E. (1995). Credit efficiency in centralized and decentralized economies. Review of Economic Studies, 62, 541-555.

Furfine, C.H. (2001). Banks as monitors of other banks: Evidence from the overnight federal funds market. Journal of Business, 74, 33-57.

Haber, S.H. (2004). Mexico's experiment with bank privatization and liberalization, 19912004. Journal of Banking and Finance, 30(5), 56-75

Hellwig, M. (1991). Banking, financial intermediation, and corporate finance. In A. Giovanni, \& C. Mayer (Eds.), European Financial Integration. Cambridge University Press, Cambridge, England: 35-63.

Islam, K. M. A. (2017). Financial Statement Analysis of Beximco Synthetics Limited. Asian Finance \& Banking Review, 1(1), 93-100. https://doi.org/10.46281/asfbr.v1i1.1250 
Ikhide, S. I. \& Alawode, A.A. (2002). On the sequencing of financial liberalisation in Nigeria. The South African Journal of Economics, 70(1), 95-127

Keynes, J. M. (1936). General theory of employment, interest rates and money. London Macmillan.

Kader, S. A., Rahman, A. A. A., Meero, A., Islam, K. M. A., Zayed, N. M., Hasan, K. B. M. R. (2021). COVID-19: After Effects of Coronavirus and Its Impact on Global Economy. Academy of Strategic Management Journal, 20(1). 1-9 Retrieved from https://www.abacademies.org/articles/covid19-after-effects-of-coronavirus-and-itsimpact-on-global-economy-11472.html

Kuznets, S. (1995). Economic growth and income inequality. The American Economic Review, 45(1), 1-28.

La Porta, R., Lopez-de-Silanes, F., \& Zamarripa, G. (2003). Related lending. Quarterly Journal of Economics, 35(12), 36-50

Lucas, R.E.J. (1988). On the mechanics of economic development. Journal of Monetary Economics, 22, 3-42

Maurer, N., \& Haber, S. H. (2004). Related lending and economic performance: Evidence from Mexico. Stanford University, mimeo.

Mckinnon, R. I. (1973). Money and capital in economic development brooking institution Washington, DC

Morck, R., \& Nakamura, M. (1999). Banks and corporate control in Japan. Journal of Finance, 54, 319-340.

Morgan, D. (2002). Rating Banks: Risk and uncertainty in an opaque industry. American Economic Review, 92, 874-888.

Myers, S. C. \& Majluf, N. S. (1984). Corporate financing and investment decisions when firms have information investors do not have. Journal of Financial Economics, 13, 187-222.

Neusser, K. \& Kugler, M. (1998). Manufacturing growth and financial development: Evidence from OECD Countries, Review of Economics and Statistics, 80(4), 638646.

Patrick, H. (1966). Financial development and economic growth in underdeveloped countries. Journal of Economic Development and Culture Change, 14(2), 174 -189

Rajan, R. G. (1992). Insiders and outsiders: The choice between informed and arms-length debt. Journal of Finance, 47, 1367-1400.

Rahman, A. A. A., Darwish, S., Meero, A., Zayed, N. M., Islam, K. M. A., Raisa, T. S. (2021). EMERGING STRATEGIES AND ECONOMIC IMPACT OF COVID-19: A CASE STUDY OF GULF COOPERATION COUNCIL COUNTRIES (GCC). Academy of Strategic Management Journal, 20(1). 1-10 Retrieved from https://www.abacademies.org/articles/emerging-strategies-and-economic-impact-ofcovid19-a-case-study-of-gulf-cooperation-council-countries-gcc-11270.html

Rajan, R. G., \& Zingales, L. (2003). Saving capitalism from capitalist. Crown Business, New York.

Robinson, R. J. (1952). The Generalization of the general theory. In the rate of interest, and other essays. London: Macmillan, 67-142.

Rahman, A. A. A., Meero, A., Zayed, N. M., Islam, K. M. A., Rabban, M. R., Bunagan, V. D. R. (2021). Impact of Leverage Ratios on Indicators of Financial Performance: Evidence from Bahrain. Academy of Strategic Management Journal, 20(3). Retrieved from 
https://www.abacademies.org/articles/impact-of-leverage-ratios-on-indicators-offinancial-performance--evidence-from-bahrain-11166.html

Shaw, S. E. (1973). Financial deepening and economic development. New York: Oxford University Press.

Shahriar, M.S., Hasan, K.B.M.R., Hossain, T., Beg, T.H., Islam, K.M.A., \& Zayed, N.M. (2021). Financial decision making and forecasting techniques on project evaluation: a planning, development and entrepreneurial perspective. Academy of Entrepreneurship Journal, 27(4), 1-7. Retrieved from https://www.abacademies.org/articles/Financialdecision-making-and-forecasting-techniques-on-project-evaluation-a-planningdevelopment-1528-2686-27-4-553.pdf

Shahriar, M. S., Islam, K. M. A., Zayed, N. M., Hasan, K. B. M. R., \& Raisa, T. S. (2021). The Impact of COVID-19 on Bangladesh's Economy: A Focus on Graduate Employability. The Journal of Asian Finance, Economics and Business, 8(3), 1395-1403. https://doi.org/10.13106/JAFEB.2021.VOL8.NO3.1395

Stern, N. (1989). The economics of development: a survey. The Economic Journal, 99(397), 597-685.

Weinstein, D. E., \& Yafeh, Y. (1998). On the costs of a bank-centered financial system: Evidence from the changing main bank relations in Japan. Journal of Finance, 53, 635672.

Wenger, E., \& Kaserer, C. (1998). The German system of corporate governance: a model which should not be imitated. In S.W. Black., \& M. Moersch, (Eds.), Competition and convergence in financial markets: The German and Anglo-American Models, NorthHolland Press, New York, 41-78.

\section{Copyrights}

Copyright for this article is retained by the author(s), with first publication rights granted to the journal. This is an open-access article distributed under the terms and conditions of the Creative Commons Attribution license (http://creativecommons.org/licenses/by/4.0). 